\title{
Development of SMS Mobile Technology for M- Learning for Distance Learners
}

\author{
doi:10.3991/ijim.v3i2.724 \\ Dr. Issham Ismail and Prof. Rozhan M. Idrus \\ Universiti Sains Malaysia, Penang, Malaysia
}

\begin{abstract}
The evolution of technologies as well as Internet application has created new ways of communication which gives impact to all regions and sectors including educators and learners in Higher-Education Learning institutions in Malaysia. Virtual learning environments as well as elearning applications are some of pedagogical mechanisms which may sound easy and quick to be applied but unfortunately they are rarely used. This research attempts to introduce m-Learning as "Convenience Education" (CE). This study will determine the design which suits the system, to identify the suitable content and hardware. The study expected to develop the system framework, the content as well as the hardware, to make recommendations on the existing learning mechanisms and to develop a framework that contributes to the improvement of the education system in Malaysia. This paper includes a pilot project using short message service (SMS) - mobile technology for a Physics course for distance learners at the Universiti Sains Malaysia.
\end{abstract}

Index Terms-mobile learning, distance education, mobile technology, convenience education

\section{INTRODUCTION}

The evolution of technologies as well as internet application has created new ways of communication which gives impact to all regions and sectors including educators and learners in Higher-Education Learning institutions in Malaysia. Virtual learning environments as well as e-learning applications are some of pedagogical mechanisms which may sound easy and quick to be applied but unfortunately they are rarely used. This sends a signal that education institutions is not actually practising the specialties of these communication. Instead, they rather adopt traditional classrooms due to lack of wired Internet access and IT support. While e-learning application is more to "Distance Education", this research attempts to introduce new pedagogical in m-Learning as a "Convenience Education" (CE).

Mobile technology such as mobile phones and short message service (SMS) are now becoming inextricably part of students' life. Within educational environments, students frequently move venues [1], but their personal mobile phones are characteristically at hand or in-thepocket with access rates well beyond the typical study or work day [2]. Due to their small size and familiarity, mobile phones in the classroom can be unobtrusive [3], require no technology training, and are not intimidating to most users.

Despite its popularity, mobile learning (m-learning) or "Convenience Education" CE is still in its infancy and in an embryonic stage. M-learning intersects mobile computing with e-learning; it combines individualized (or personal) learning with anytime and anywhere learning [4]. It is facilitated by a convergence of Internet, wireless networks, W/H devices (Wireless phones and handheld devices) and e-learning. With a W/H device, the relationship between the device and its owner becomes one-to-one, always on, always there, location aware, and personalized [5]. The place independence of $\mathrm{W} / \mathrm{H}$ devices provides several benefits for e-learning environment like allowing students and instructors to utilize their spare time while traveling in a train or bus to finish their homework or lesson preparation [6].

The impact of using mobile communication technology to spread learning material and increase informal interaction has been rarely studied [7]. Initial studies done on the usage of mobile technology have shown the usefulness of mobile technology in education [6]. More interactions which can lead to a more active learning have been observed when SMS was used [8]. Distance educators are being challenged to respond to this changing environment that is enhancing effectiveness of learning from Distance Education (DE) to Convenience Education (CE) for learners.

\section{The Mobile LeARning (CONVENIENCE EDUCATION)}

The mobile phone is now part of the learner make-up in their everyday life. As much as they need to undertake their educational activities, they value their time more in terms of what they need to get out of that material quickly. Naturally, the educational design considerations in the use of mobile phones are;

1. The systematic chronological presentation of course materials.

2. Presentation of 'daily' chunk of information; learning tips, laws, rules, simple formula, definitions, rhetoric, quiz, points to ponder, glossary, everyday examples etc.

3. The materials should available in diverse formats either to use text, image, audio or video according to the systems they are using; GPRS or 3G.

4. Content can be experientially real to students in the sense that they can engage in personally meaningful activity/ learning.

5. Capability of return message for further action.

6. Incorporate SMS with electronic portal for archival purposes.

7. Incorporate interaction (via forum) in the electronic portal.

8. Creation of student group via the hand phone.

9. Easy interface. 
10. Utilise capabilities of hand phone such as saved messages etc.

The use of SMS (Short Message Service) between cell phones or between the internet and cell phones is now an accepted part of everyday social communication. MSupport introduces technology which promotes flexibility beyond that offered through current e-learning resources.

There were several factors that were considered in the course of deliberating this SMS project for the selected courses:

- The mobile phone is now a testament of a media tool that can be utilized anytime and anywhere. Hence the hand phone is always with the students and text message can be sent regardless of the geographical location of the students.

- The Short Message Service or SMS function can be utilized as an asynchronous form of communication with a student, fostering a sense of connectivity between the lecturer and student and facilitating a supportive learning environment.

- Using the personal mobile phone gives an opportunity for a short piece of information to be delivered to the students without constrain of space and time and also linkage issues of the Internet.

- The mobile phone will be an immediate bridge in communication and activity before a more comprehensive discussion could ensue in the electronic portal. This communication is important as sometimes the lecturer may be too busy to pay the portal a visit while the students are waiting for some form of feedback from faculty.

- The study of Physics could benefit from snippets of lesson sent daily that may facilitate for short learning experiences before the students can a chance to do some serious work later on.

- The use of mobile technology will complement the electronic portal in terms of learning activity and experiences.

\section{OBJECTIVE(S) OF THE RESEARCH}

The research is expected to design, develop, implement, analyse and evaluate the complete system of m-learning technologies. The system, content and hardware of mlearning are expected to be designed, developed, implemented, analysed and evaluated in this process.

The research will determine the factors that affects mlearning amongst learners. Later, it will identify factors that influence learners' acceptance or rejection of mlearning. Finally we will identify the effectiveness of using mobile phones as a CE medium.

\section{MethodOLOGY}

The research will study three different components of m-learning. Section 1 will focus on the Content Development. Initially, the content development will be conducted where the researcher will identify the suitable content and start to design the content. Then, the content will be developed in different form of media; text, image, audio or video. Through with this process, literature review also will be conducted. Contents implementation is reviewed. Then, all the content will be merged and synchronized with artificial intelligence system.
Section 2 will be dedicated for System Development. At the meantime, the researcher will develop the system by identifying the design which best suits m-learning. Then, the constraints and the advantages of the design will be identified and figured the best medium to be used. After that, the system will be developed. Then, the researcher will conduct a discussion with system analysts to identify the suitable and appropriate medium and system requirement. At this stage, system is improved and implement.

Section 3 will be used for Software and Hardware Development. This section only will be managed after completing the section one and two. At this stage, consultations with system analysts will continuously conduct to identify the suitable hardware and software to be used. After that, the hardware will be designed. Then, the development of the hardware will be conducted. Next, the hardware will be installed and simple pre-test run will be conducted. At the meantime, the software/program of the system will be designed by the consultant. Then, the program will be developed by the consultant. After that, the program will be installed into the system. Software and hardware are synchronised for the implementation process.

Later, the AI system will be run to the respondent by using m-learning pedagogy technique. Questionnaire will be distributed to the respondent upon feedback on the course content preparation, preparation of the technology device interchange and finally to identify factors that influence learners' acceptance or rejection of artificial intelligence system. Qualitative and quantitative analysis will be conducted. After the correction and improvement of the system have been made, the launch for the prototype of the m-learning system will be conducted.

\section{PILOT STUDY}

The course selected for the pilot study was the second year Physics optics course with the code JIF212. The topic selected was "dispersion" and this is the current topic that the students should be attending to in their self-study according to the flow of content in the course. This specific course is being managed by one of the authors (RMI) and lends itself well to this project as it contained many definitions and is information-rich; constructing daily text messages based on the content would act as a natural pace to the students.

One of the main thrust of this project is to incorporate pacing by constructing the text message according to the sequence of topics in the learning materials. The fact that they had been instructed to copy, by hand, each message into their note book would instill the habit of writing down the facts and definitions as well as tips sent to them. More serious deliberations will be conducted via the Forum in the electronic portal; the event being initiated via the SMS. This technique would lead to an optimization of the Forum and the sharing of discussion of the relevant topics. The students were discouraged from sending one on one e-mail to the course manager as this would not benefit all the students in the course.

13 students responded to the questionnaire, giving a return rate of $76 \%$. The questionnaire consisted of 10 questions in an effort to extract the perception of the students in this unique use of the short message service to facilitate the learning of Physics. A negative statement 
was inserted in the middle of the questionnaire to ascertain that the students actually read all the questions in earnest to avoid a habitual check of responses.

The statements were designed to capture many aspects of the teaching and learning processes as well as communications in the physics course and the delivery mechanisms involved. It was imperative that the students understood the instructions and the text messages sent. After all, the messages were constructed in reference to the text book that is being used or the course. The responses to the questionnaire are given in Table 1.

The overwhelming agreement may prove that the mobile phone could make a strong and viable contribution to the educational transaction in a Physics course in distance education. The response to the questionnaire and the additional comments by the students reflected a tremendous success to this project. In fact, the course manager keep getting e-mail messages from the students for the text messages to be continued till the end of the semester, incorporating short message notes for revision for the forthcoming final exam in April 2008.

TABLE I.

RESPONSE TO THE SMS (SHORT MESSAGE SERVICE) PILOT STUDY FOR PHYSICS TOPIC AT THE SCHOOL OF DISTANCE EDUCATION

\begin{tabular}{|c|c|c|c|c|c|c|c|}
\hline & Statement & $\mathbf{N}$ & 1 & 2 & 3 & 4 & 5 \\
\hline 1 & $\begin{array}{l}\text { I could understand the } \\
\text { instructions regarding the } \\
\text { SMS project that was sent in } \\
\text { the electronic portal }\end{array}$ & 13 & & & $15 \%$ & $31 \%$ & $54 \%$ \\
\hline 2 & $\begin{array}{l}\text { I had no problems receiving } \\
\text { the text messages from my } \\
\text { lecturer }\end{array}$ & 13 & & & & $23 \%$ & $77 \%$ \\
\hline 3 & $\begin{array}{l}\text { I could understand the daily } \\
\text { text message received from } \\
\text { the lecturer }\end{array}$ & 13 & & & $23 \%$ & $46 \%$ & $31 \%$ \\
\hline 4 & $\begin{array}{l}\text { The daily text message } \\
\text { helped me in my studies of } \\
\text { the Physics course }\end{array}$ & 13 & & & $15 \%$ & $31 \%$ & $54 \%$ \\
\hline 5 & $\begin{array}{l}\text { I found receiving the daily } \\
\text { text message from my } \\
\text { lecturer to be an } \\
\text { inconvenience }\end{array}$ & 13 & $69 \%$ & $31 \%$ & & & \\
\hline 6 & $\begin{array}{l}\text { Text messages from my } \\
\text { lecturer helped to motivate } \\
\text { me to study }\end{array}$ & 13 & & & & $31 \%$ & $69 \%$ \\
\hline 7 & $\begin{array}{l}\text { Text messages from my } \\
\text { lecturer helped to motivate } \\
\text { me to study }\end{array}$ & 13 & & & & $3 \%$ & $77 \%$ \\
\hline 8 & $\begin{array}{l}\text { Text messages promoted } \\
\text { flexibility by enabling } \\
\text { communication with my } \\
\text { lecturer regardless of time } \\
\text { and place. }\end{array}$ & 13 & & & & $15 \%$ & $85 \%$ \\
\hline 9 & $\begin{array}{l}\text { I could afford the financial } \\
\text { cost of text message } \\
\text { communication with my } \\
\text { lecturer }\end{array}$ & 13 & & & $8 \%$ & $54 \%$ & $38 \%$ \\
\hline 10 & $\begin{array}{l}\text { Text messaging should be } \\
\text { introduced as a standard } \\
\text { form of support for Physics } \\
\text { students }\end{array}$ & 13 & & & & $46 \%$ & $54 \%$ \\
\hline
\end{tabular}

\section{CONCLUDING REMARKS}

The mobile phone has replaced land lines as the main basic communication mode, reaching even remote areas and poor countries. The use of the mobile phone in an educational transition can be akin to a new basic education format like the chalkboard was. Our use of the SMS Physics notes in the most basic way has achieved tremendous support from as well as benefit to the students. We look forward to our next step for a more comprehensive architecture of M-Learning and participation from more courses so that we can design the courses appropriately for the convenience of the students.

\section{REFERENCES}

[1] Muhlhauser, M. \& Trompler, C. (2006). Learning in the digital age: paving a smooth path with digital lecture halls. In IEEE 35th Hawaii International Conference on System Sciences, Hawaii

[2] Cereijo-Roibas, A., \& Arnedillo-Sanchez, I. (2002). Pathway to m-learning. In European workshop on mobile \& contextual learning, Birmingham, UK.

[3] K. Nyiri. (2003). Mobile communication: essays on cognition and community, Passagen Verlag, Vienna

[4] C. Quinn, (2001). Get ready for m-learning, Training and Development 20 (2)

[5] S. Homan and K. Wood, (2003). Taming the mega-lecture: wireless quizzing, Syllabus Magazine

[6] M. Virvou and E. Alepis, (2005). Mobile educational features in authoring tools for personalized tutoring, Computers and Education 44 (2005),

[7] Rau, P.-L.P, Gao, Q., \& Wu. L.-M. (2008). Using mobile communication in high school education: Motivation, pressure and learning performance. Computers and Education 50

[8] C. Markett, I. Arnedillo Sánchez, S. Weber and B. Tangney (2005) "PLS Turn UR Mobile On”: Short message service (SMS) supporting interactivity in the classroom. In: Kinshuk, Demetrios G. Sampson and Pedro Isaias (2004), Editors, Cognition and exploratory learning in digital age, International Association for Development of the Information Society, Lisbon

[9] Chen, S.H., Jakeman, A.J.,\& Norton, J.P. (2008). Artificial Intelligence techniques: An introduction to their use for modeling environmental systems. Mathematics and Computers in Simulation 78 (2008),

[10] Costa, A.L., and Kallick, B. (2004). Assessment strategies for selfdirected learning. Thousand Oaks, CA: Sage Publications.

[11] Mackay, B.J. (2007). Using SMS mobile technology to M-Support nursing students in clinical placements. Paper presented at the eFest Conference 27th-29th September, Wellington, New Zealand, http://www.coda.ac.nz/cgi/viewcontent.cgi?article=1000\&context =northtec_nh_cp

[12] Price, S., Rogers, Y., Stanton, D. and Smith, H. (2003). A new conceptual framework for CSCL: Supporting diverse forms of reflection through multiple interactions. In CSCL'03,Kluwer Academic Publishers

[13] Schön, D.A. (1983). The reflective practitioner: How professionals think in action. Basic Books

\section{AuTHORS}

Issham Ismail is with the School of Distance Education, Universiti Sains Malaysia, Minden, Pulau Pinang, 11800 Malaysia (e-mail: issham@usm.my).

Rozhan M. Idrus is with the School of Distance Education, Universiti Sains Malaysia, Minden, Pulau Pinang, 11800 Malaysia. He is specialized in Open and Distance Learning Interactive Technologies and eLearning (e-mail: rozhan@usm.my).

This work was supported in part by the Universiti Sains Malaysia under RU Grant 1001/PPJAUH/817015.

This article was modified from a presentation at the 5th Congress of Scientific Research Outlook in the Arab World (SRO'5) in Fez, Morocco, October 2008. Manuscript received 07 November 2008. Published as submitted by the authors. 